\title{
Hospitality environmental factors: a study of the consumption experience of homosexuals in the Northeast of Brazil
}

\author{
Yákara Vasconcelos Pereira Leite ${ }^{\mathrm{i}}$ \\ Universidade Federal de Pernambuco (Brazil) \\ Juliana Pinheiro da Silva ii \\ Manuela Souza Constantino Oliveira ${ }^{\text {iii }}$
}

\begin{abstract}
The overall goal of this research is identifying environmental factors in hospitality that lead the interviewed homosexuals to memorable consumer experiences at hotels and inns. This research was conducted under descriptive qualitative approach. According to this perspective, gays from two states of the northeast of Brazil were interviewed. The narratives were presented in order to enhance the formation of categories. Regarding results, it was observed that the experience of consumption is memorized as positive or negative due to the performance of factors related to service provision and infrastructure. Therefore, it was noticed that the hospitality servicescape influences the consumption experience of the interviewed homosexuals to a point that it becomes memorable.
\end{abstract}

Keywords: Consumption experience; Hospitality; Homosexuals; Experiential marketing; Consumer subculture.

Título: Factores del ambiente de la hospitalidad: un estudio de la experiencia de consumo de homosexuales del Nordeste Brasileño

Resumen: Esta investigación tiene el objetivo general de identificar los factores ambientales de la hospitalidad que impulsan los homosexuales entrevistados a vivieren experiencias memorables de consumo en los hoteles y hostales. Se utilizó el enfoque cualitativo de tipo descriptivo. Desde esta perspectiva, gays de dos Estados del Nordeste de Brasil fueron entrevistados. Los relatos se presentaron a fin de mejorar la formación de categorías. En cuanto a los resultados, se consideró que la experiencia de consumo se almacena como un rendimiento positivo o negativo debido a factores relacionados con la prestación de servicios y la infraestructura. Por lo tanto, se constató que el entorno de servicios de hospitalidad influye en el consumo de los homosexuales entrevistados a punto de hacerla memorable.

Palabras clave: Experiencia de consumo; Hospitalidad; Homosexuales; Marketing experiencial; Subcultura de los consumidores.

\footnotetext{
i Professora do Departamento de Agrotecnologia e Ciências Sociais da Universidade Federal Rural do Semi-Árido e doutoranda em Administração da Universidade Federal de Pernambuco (Brazil). E-mail: yakarav@gmail.com

ii Graduada em Hotelaria pela Universidade Federal de Pernambuco (Brazil). E-mail: julianapds@hotmail.com

iii Aluna do International Master of Science in Business Administration - UCP/ FCEE. E-mail: manu.scoliveira@gmail.com
} 


\section{Introduction}

Helping organizations capture and retain clients is one of the goals of studies that investigate consumer behavior. Hence this challenge, the buyer not only receives information before the acquisition of a product or service, but also during and after this process.

Due to this idea, experiential marketing focuses on providing a differentiated consumer experience so the client feels satisfied and repeats the purchase (Schmitt, 1999). Consumer experiences may take place at different settings, such as shows, operas, restaurants, cinemas, hotels and others. In the case of a hotel environment several factors contribute for the production of memories related to a differentiated and pleasant stay on a guest's mind (PORIA, 2006). This can make the client return to the hotel in the future or indicate it to other potential consumers.

This way, this investigation consists on identifying consumer experiences at hospitality settings that are memorable for a group of interviewed homosexuals. This subculture of consumption (Peñazola, 1996; Kates, 1998, 2002; Nunan, 2003; Pereira, Ayrosa y Ojima, 2005) has been little explored by researchers and entrepreneurs, although it represents great profit opportunities. This public is formed by the GLBTs (gays, lesbians, bisexuals, transgender people - and supporters) group; this research refers to a group of both male and female gays.

Thus, the present work is structured into seven sections. Besides this one, second and third sections portray a theoretical approach to the thematic of subculture and consumer experience. Then, the procedures, results, final considerations and references are presented.

\section{Subculture: Homosexual Consumer}

Mowen and Minor (2003, p.3) explain that: "Consumer behavior is defined as the study of the buying units and the exchange processes involved in acquiring, consuming, and disposing goods, services, experiences, and ideas". Solomon (2008) follows a similar perspective, stating that several factors influence consumer behavior, among them the marketing stimuli, macro-environment, individual factors and characteristics, and also the subculture.

Besides culture, there's also the subculture, thus, Mowen and Minor (2003: 36) state:

[...] culture as the way of life of people in a society. On the other hand, a subculture is a subdivision of a national culture. The subculture is based on some unifying characteristics [...] and its members share a similarity of behavior somewhat distinct of the national culture in which they live.

Hooley, Saunders and Piercy (2005) go further, explaining that every individual can take part in a variety of subcultures. The subcultures are groups within society that have unique characteristics regarding their attitudes or behavior. In order to have some importance for the investigations, it is recommended to observe if the participants of the analyzed subculture have long-lasting behaviors, and also that these are of great importance, affecting the attitudes of such individuals. This is verified in the case of homosexuals.

Based on social movements, homosexuals have developed an awareness of themselves, which is the result of common interests and experiences of exclusion, mobilization and mistreatment by the dominant society (Penãzola, 1996). For this reason, homosexuals were classified in the market as a subculture of consumption, since the subculture of consumption is "a socially constructed phenomenon" (Nunan y Jablonski, 2002, p. 21) and gathers individuals with similar lifestyles, values, attitudes and beliefs - that are opposite to the ones of the dominant culture (Delozier y Rodriguez, 1996; Kates, 1998; Nunan, 2003). By being grouped into a subculture of consumption, it becomes easier to be identified and included in consumption patterns through the different dimensions of identity, social practices and formation of communities (Penãzola, 1996). Thus, a subculture is made up of "meanings, codes, language, norms, values, customs, activities, institutions (material and psychological support structures) and traditions" (Nunan y Jablonski, 2002, p. 21).

Oliveros and Lopez (2006), Oakenfull and Greenlee (2005) and Oliveira (2002) complement this point of view by stating that the gay community is an attractive consumer market because it is composed of couples with dual incomes and no children, that also possess a high level of culture, which encourages them to spend more on leisure. Due to the interesting buying potential offered by the homosexual community, Newman and Nelson (1996: 57-58) argue that marketers "are beginning to recognize homosexuality as a way of life."

Another aspect is that the most solid studies in the literature on consumption behavior of homosexuals were conducted by foreign researchers in their country of origin (Delozuier y Rodrigue, 1996; Fugate, 1993; Haslop, Hill y Schmidt, 1998; Hughes, 2002 ; Kates, 1998, 2002; Lukenbill, 1999; Reiss y Webster, 1997). However, despite the fact that these studies have been developed abroad, Nunan (2003) states that the consumption behavior of foreign homosexuals is similar to the one in Brazil. Furthermore, regardless of social class, gay men value the image, appearance and fashion and, moreover, are directed to information and entertainment, which means that they seek information about fashion, personal relationships and about what is happening in the world.

Homosexual tourists' interests are related to cultural activities, urban tourism, and sites that do not show homophobic attitudes (Hughes, 2002). This happens when other individuals in society disapprove homosexuality and, therefore, there is often a high probability of physical or verbal aggression to the homosexual. 
Jones (1996) explains that there is still discrimination against same-sex couples and that it could be noticed even during bookings/ reservations. Considering this aspect, the term "gay" adopted along the study refers to both male and female gays and does not intend to be regarded as pejorative.

According to Lukenbill (1999: 52), "the gay travel a lot, both domestically and abroad". Nunan (2003: 161) states that this occurs "quite frequently" and that they tend to choose destinations where "there is greater sexual freedom or an established gay community. This is because for gays the concept of freedom covers various spheres of social life, including consumption, patterns of behavior and sexuality, being a relevant factor in this subculture (Visconti, 2008). The reason to go on several leisure trips is closely related to the high stress level that homosexuals face on a daily basis (Lukenbill, 1999). To this group, travelling comes as an alternative that allows them to set themselves free from heterosexuality, and this leads to a search for places where they may, in one way or another, "discover or be themselves by the performance of gender and sexual roles" (Waitt y Markwell, 2006, p. 4). This freedom can be expressed in hotels, providing memorable consumer experiences. The following section presents an overview of this topic.

\section{Memorable consumer experiences}

Experiences can last a long time in people's minds (Schmitt, 2002), becoming memorable (Nsip y Gilmore, 1998).

\section{Memory}

The acknowledgement of the buyer's needs of happens once the difference between an actual and a desired condition is noticed (Mowen y Minor, 2003; Solomon, 2008). Depending on its needs and desires, the consumer may get more involved with the buying process.

Zaichkowsky (1985) defines involvement as the relevance of a perceived object based on a person's needs, values and interests. It is expected that the more the customer is involved, the more attention is paid in order to understand the information related to products and services (Mowen y Minor, 2003). Solomon (2006), Mowen and Minor (2003) warn marketers that they should expose consumers to information, making them pay more attention to the product. When there is attention, cognitive capacity is directed towards a stimulus, in a way information is processed consciously. Cognition is the area in which all mental phenomena, perception, memory, judgment and reasoning are grouped (Bayton, 1958). In the case of memory, it "influences the process of attention, orienting the sensory system to focus, according to its own choice, on a specific stimulus (Mowen y Minor, 2003, p. 64).

Memory is formed by long-term memory (LTM), shortterm (working) memory (STM) and sensory memory (SM) systems. The information is captured by one or more re- ceptors (sight, smell, touch, etc.) and transmitted to an appropriate SM, where it is rapidly lost (in fractions of seconds), unless attention is allocated to the stimulus. The received information is transferred to the STM, which performs as the center of the processing activity since it integrates information from sense organs and the LTM (Shimp, 2003).

The internal construction of consumer reality may not be congruent with the outside world, i.e. the world objectively verifiable. Because of this, researchers should probe the mental image that consumers establish towards a product, as seen in the consumer's subjective reality thus, beyond its objective context. The hedonic approach raises important questions about the mental role, such as multisensory images and emotional arousal (Hirschman y Holbrook, 1986), in order to complement this discussion, follows some information about the analyzed subculture's experience of consumption.

\section{Consumption experiences of homosexuals}

In contrast to traditional marketing - which focuses on features and benefits, the experiential marketing focuses on consumer experiences. Experiences occur as a result of meetings, suffering or simply living. Experiences promote sensations, feelings, cognition, behavior and a relationship value that replaces the functional value. In recent times, there is a growing trend to provide consumer experiences, especially in the service sector (Berry, Carbone y Haeckel, 2002; Pullman y Gross, 2003). Currently, the concept of experience in marketing involves offering something more attractive to buyers (Wikström, 2004).

According to Schmitt (2002: 77), which is one of the most relevant scholars on this subject "experiential marketing is based on the client's psychological theory and practice - as well as their behaviors." Thus, it is related to hedonic consumption. To Hirschman and Holbrook (1986: 92), the "hedonic consumption relates to facets of consumer behavior that relate to the multisensory, fantasy and emotive aspects of one's own experience with the products." The concept is linked to the pleasure that is captured via the senses of the consumer. It is an approach that aims to examine the interaction between consumers and products. Hedonic products have a high reliance on sensory aspects (Woods, 1960). Thus it provides a further justification for studying the homosexual consumption in hospitality.

Holbrook and Hirschman (1982) present a model that represents the variables in consumer behavior. The focus is on symbolic, hedonic and aesthetic nature of consumption. They add that the choice of products depends largely on the subculture.

The service encounter, which is known as the "Dyadic integration that occurs between service providers and customers" is considered the starting point in customer service ratings (Saura et al., 2005: 50). The experiences of consumption in services are therefore the result of these interactions between "organizations, systems/processes related, employees and consumers" (Bitner et al., 1997: 
193). The consumption experiences are created, moderated and mediated by emotions that are a state of mind that comes from evaluations of an event or thought and can generate specific actions depending on the nature and the thoughts of the individual (Gutiérrez, 2006).

This way, efforts to create emotional connections with consumers through effective planning of tangible and intangible aspects of services have achieved greater importance to hospitality businesses (Pullman y Gross, 2003). Dube, Le Bel and Sears (2003: 125) believe it is possible to manage different objective elements, such as physical environment, human resources and communication in order to "shape guest's perceptions in order to create satisfying experiences", because according to the authors, the specific aspects of hotels operate as providers of private benefits that are stored in the minds of guests.

The importance of the social elements in mutual exchanges of service was considered by Butcher (2005), especially in hospitality services, where there is close contact between customers and employees. The author defined two social variables (social comfort and social value) capable of influencing consumer behavior and, consequently, the results of the service, such as repurchase intentions. The social comfort was defined as the "consumer's feelings of anxiety or relaxation arising from social interaction with the employee's service." The feelings of comfort come from the behavior of others on site, therefore, within the service interactions, are often dependent on actions by hospitality employees. The second variable - social value, concerns the value and importance feelings demonstrated by service providers to their clients during service (Butcher, 2005).

In order to explain how the process of consumer experience in hospitality takes place and is constructed, Knutson and Beck (2003) developed a theoretical model divided into three specific parts. The first part of the model consists of the stage of "pre-experience" of consumption, which includes the expectations created by the brand, promotional activities, advertising campaigns and the personal memories stored in a previous experiment. The second part is considered the "heart" of the model and represents all service encounter experiences. In hospitality, this part of the model is related to all stages that guests go through, including booking the hotel, the stay itself and check-in and check-out procedures. It is emphasized that the degree of accessibility of the service may affect the value of experience perceived by customers. The accessibility within consumer experiences relates to cost, delivery and service availability at the time the consumer desires to buy it. The third part of the model consists of the "postexperience" built on the perceived personal aspects of guests in relation to the experience and on the value and satisfaction that they attribute to the experience. On the third part of the model the authors also include customer complaints and resolutions, through feedback after consumption, to then complete the whole process of consumption experience.

Some studies concern about the influence of the servi- cescape on the consumer experience of homosexuals. In service companies related to leisure - including hotels, consumption has been induced by emotional reasons. More recent studies corroborate this perspective (Lally y Fynes, 2006). It is known, however, that the responses of an individual or a group of individuals, caused by the atmosphere at a given time may be different in another group (Turley y Millimam, 2000). According to Kates (1998), who studied the homosexuals, the complex set of meanings represented by beliefs, standards, values, traditions and practices is the foundation of human activities and help shape the way people use products.

Bars, restaurants and clubs aimed at the homosexual audience also cause internal reactions that are important to the understanding of gay consumer behavior. In these settings, homosexuals keep their network of friends, socially interact with others and can freely express their cultural identity and sexual orientation (Hughes, 2002).

The importance of the environment on leisure services as a factor of great influence in the homosexual consumer experience was studied by Haslop, Hill and Schmidt (1998). In a survey conducted on gay bars in the city of Manchester in the United States, the researchers found that gay men who have experienced the services offered in the gay bars of the city had feelings of freedom, liberation, safety and social participation. Two key influences of environmental services that attracted and pleased gay customers were music and atmosphere. The atmosphere was presented as an "integration of all aspects of the environment", composed by music, decor and other customers, this corroborates the research developed by Ruangwanit and Wattanasuwan (2009), which presents decoration as an important aspect to the male homosexual.

Haslop Hill and Schimidt (1998) also found the more apparent values among homosexual consumers during experiences in a service encounter environment and their findings include security, the opportunity to express oneself, freedom, community, individualism, hedonism and diversity. Therefore, it could be noticed that the "subculture of consumption helps the individual to resolve various problems which are related to the need for freedom, identity, affiliation with others" (Kates, 1998, p. 132).

Another relevant research was conducted by Poria (2006) and examined the experiences of gay consumption in hotels. According to this research it is significant for homosexuals to feel welcome and accepted once their sexual orientation is known. For this reason, the participants considered important that hotel workers allocate gay couples in double bed apartments. For this group it has a symbolic meaning because it is in the allocation of apartments with double bed that they realize that their sexual orientation is accepted by the establishment. According to Poria (2006, p. 330), "almost all participants said they would like to feel they are being treated and served by staff the same way as the other guests." Besides that, interviewed homosexuals also gave importance to the place's security and extended breakfast.

Once the theoretical framework that conducted data 
collection and analysis has been presented, the following section describes the methods applied to this research.

\section{Methods}

In order to achieve the overall objective, a qualitative approach has been adopted (Merriam, 1998). "The qualitative method makes it easier to study in depth and in detail" (Patton, 2001: 14) and does not intend to generalize the results.

In relation to environmental factors that can provide memorable consumer experiences in hospitality, this research considered memories related to stays at hotels and inns, excluding thus memories of any other establishment that provides accommodation such as hostels and motels. This criterion was established due to observation of a lack of studies in this specific field.

Following the qualitative perspective, six male gays were interviewed early in the second half of 2006 in Pernambuco (PE) and ten other homosexuals, being five females and five males, responded to the interviews at the end of the first half of 2010 in Pernambuco and Rio Grande do Norte $(\mathrm{RN})$. The interval of time for data collection was determined due to access and availability of the researcher. Among these ten, three gay men and two women were from RN, whereas two homosexual males and three females were from PE.

Some criteria have been adopted to select respondents. The first was that, in order to respect the design of this investigation individuals should be publicly assumed gays. The second criterion was to admit only those respondents who stayed at hotels and/or inns within the last five years. While acknowledging that experiences "last a lifetime" (Schmitt, 2002) and its main attribute is the fact that customers consider the experiences as a "memorable event" (Pine y Gilmore, 1998, p. 98), the five year period was set in order to get closer to the period of stay. Besides these criteria, respondents also had to previously earn some college degree, even if still in progress or incomplete, once it is understood that educational level influences consumer behavior (Solomon, 2008).

The selection of these two states in the Northeast of Brazil (PE and $\mathrm{RN}$ ) was due to access to these locations. As for the selection of subjects, the first ones in Pernambuco and Rio Grande do Norte were chosen intentionally, these then indicated their contacts, according to the "snowball" technique (McDaniel y Gates, 2005) which enabled the selection of the study participants. Finally, the definition of the number of respondents occurred according to the criterion of saturation of the categories formed during data analysis (Taylor y Bogdan, 1984).

A semi structured interview was the method used for data collection. According to Jacoby (1978), the interview is an important technique when one wants to lead the respondent to recall past events. To determine the adequacy of the collection tool, the interview script went through two pilot studies, in 2006 and 2010. Two types of interviews were used, one with a predetermined script, implemented in semi-structured interviews in 2006 and 2010 and the fictional, only adopted in 2010. The fictional interview intend to bring out the subject's past experiences allowing creative freedom in the form of a narrative, beginning with a presentation by the interviewer, in a hypothetical and realistic situation, through which the interviewee can create a personal fictional narrative (Albandes-Moreira, 2002). Thus, all interviews were recorded and transcribed.

Regarding the stage of data analysis, a large amount of information is a characteristic of qualitative studies (Patton, 2001), in which the encoding appears as a systematic of development and refinement that contributes to interpretation (Taylor y Bogdan, 1984). Considering this, the collected information was encoded, so it was possible to analyze the interviews (Bogdan y Biklen, 1994). From the data coding, categories were formulated to capture aspects of the analyzed phenomenon (Merriam, 1998). Thus, we considered the repetition of words and the emphasis that respondents gave to certain themes (Bogdan y Biklen, 1994).

\section{Results}

This research aims to identify the consumer experiences at hotels and inns that are memorable for interviewed homosexuals. Regarding this purpose, the findings are presented in three stages. The first presents the positive and negative memorable experiences experienced by six male homosexuals who were interviewed in 2006 in the state of Pernambuco. The second stage presents the memorable consumption experiences remembered by the ten male and female homosexuals surveyed in 2010 in the states of Pernambuco and Rio Grande do Norte. At last, the results are discussed with the support of the theoretical framework.

The narratives were presented in order to enhance the formation of categories. This way, the narratives had to go through a selection process.

\section{Male gay's reports - Pernambuco (2006)}

Through analysis of the collected data it was observed that issues related to service, breakfast, privacy and discretion make an experience of consumption in hotels and inns memorable in a positive way to gay respondents. Table 1 presents evidences of these results by sharing sections of narratives - along with pseudonyms of respondents in parentheses. The three categories on Table 1 are classified as activities related to service delivery.

Also regarding positive experiences Table 2 lists infrastructure factors. The bed, the differential structure, pool and cable TV are responsible for creating positive memories in the minds of respondents after staying in hotels and inns.

Regarding location, Table 3 presents excerpts from the interviews that demonstrate the relevance the interviewed gays deposit in that respect. Accommodation 


\begin{tabular}{|c|c|}
\hline \multirow[t]{2}{*}{ Service } & $\begin{array}{l}{[. . .] \text { the hotel really values the offer of a personalized service [...]. Personalized service, }} \\
\text { politeness, posture, willing to serve, dealing with the situation with proper finesse [...]. } \\
\text { (João da Silva) }\end{array}$ \\
\hline & $\begin{array}{l}{[\ldots] \text { the way you are treated, that's really important, being welcome, because that's hard }} \\
\text { to find. (Gabriel Montenegro) }\end{array}$ \\
\hline \multirow{3}{*}{ Breakfast } & $\begin{array}{l}\text { [...] breakfast was exquisite, it was like a convention Center, everything was provided [...]. } \\
\text { (Gabriel Montenegro) }\end{array}$ \\
\hline & $\begin{array}{l}\text { I think the breakfast should offer diversification, because it's different, right? [...] (Antônio } \\
\text { Cavalcanti) }\end{array}$ \\
\hline & $\begin{array}{l}\text { [...] you come to breakfast, the food is good, not as in just offering better quality but a } \\
\text { well prepared meal. (Eduardo Assis) }\end{array}$ \\
\hline \multirow{3}{*}{ Privacy and discretion } & $\begin{array}{l}{[\ldots] \text { they won't invade your privacy, what matters to them is that you feel good when you }} \\
\text { stay there }[\ldots] .[\ldots] \text { to me, discretion is fundamental [...]. (João da Silva) }\end{array}$ \\
\hline & Discretion, because they'll be dealing with all sorts of people [...]. (Gabriel Montenegro) \\
\hline & $\begin{array}{l}\text { I believe it should be as discrete as possible, providing regular service, making the guest } \\
\text { feel as comfortable as possible. (Pedro Araújo) }\end{array}$ \\
\hline
\end{tabular}

Table 1 Positive consumption experiences - Service provision (2006). Source: data collected in 2006

\begin{tabular}{|c|c|}
\hline \multirow{3}{*}{ Bed } & $\begin{array}{l}\text { The bed! Sleeping is very good [...] The bed must have a nice mattress, a good pillow } \\
\text { - neither too high nor too low, maybe a duvet according to the temperature [...]. } \\
\text { (Antônio Cavalcanti) }\end{array}$ \\
\hline & $\begin{array}{l}{[\ldots] \text { if there's a nice, comfortable bed and pillows, a Nice and clean bathroom and all, }} \\
\text { then it's fine [...]. As long as it's soft and comfortable [...]. (João da Silva) }\end{array}$ \\
\hline & Must offer a comfortable bed (Eduardo Assis) \\
\hline \multirow[t]{2}{*}{ Differentiated structure } & $\begin{array}{l}\text { It was a big hotel, an Othon, once you arrive you can notice the differential. It was } \\
\text { chic, there were marble columns and shops, such as: Zahra, Clock's [...]. (João da } \\
\text { Costa) }\end{array}$ \\
\hline & $\begin{array}{l}{[\ldots] \text { but there was a very beautiful balcony and you could have breakfast on this }} \\
\text { porch because it was connected to the bedrooms [...]. (Gabriel Montenegro) }\end{array}$ \\
\hline \multirow[b]{2}{*}{ Pool } & $\begin{array}{l}\text { [...] a pool with a waterfall, whirlpool, warm water etc It was all about the hotel, you } \\
\text { don't even bother going out, you just relax [...]. (Gabriel Montenegro) }\end{array}$ \\
\hline & $\begin{array}{l}{[. . .] \text { there was a heated pool, so it doesn't matter if it's winter or early morning. }} \\
\text { Another thing, I do enjoy swimming. I cherish a hotel that offers a pool where I can } \\
\text { spend some time swimming [...] (Antônio Cavalcanti) }\end{array}$ \\
\hline \multirow{2}{*}{ Cable TV } & $\begin{array}{l}\text { [...] cable TV, you have the option to watch a movie, several programs [...]. (Antônio } \\
\text { Cavalcanti) }\end{array}$ \\
\hline & $\begin{array}{l}\text { I think it's fundamental [...]. Cable TV is an essential item nowadays, it's like offering } \\
\text { an ensuite bathroom. (João da Silva) }\end{array}$ \\
\hline
\end{tabular}

Table 2 Positive consumption experiences - Infra-structure (2006). Source: data collected in 2006

[...] the location, the feasibility to go wherever you want from the hotel [...] (Gabriel Montenegro) Ibis Belo Horizonte is located in the suburb of Liberty, it is extremely central; it is extremely close to everything [...]. It is extremely hard to get a reservation there because of its location; it's in the heart of the city which really makes things easier. You can go around by foot, taxi rides become cheaper because distances are [...]. (João da Silva)

Table 3 Positive consumption experiences - Location (2006). Source: data collected in 2006 
within easy access or close to transports centers are related to the perception and memorization of the consumption experience. Thus, using these data, it is possible to understand that for the six respondents in 2006, the provision of services, infrastructure and also the location of hotels and inns are crucial to remember the moment as positive.

On the other hand, the experiences of consumption can be regarded as negative when triggered by factors related to service, availability of double bed and cleanliness. Table 4 shows the reports of respondents about the categories of services that may lead the guest to rate a stay as negative.

After data analysis, the findings indicate that the service is relevant and when poorly managed can affect the customer's memories about the stay. In what concerns the service, a couple of situations stand out - when employees do not meet the requests of guests or when they do not perform the service adequately. The category availability of double beds represents the difficulty of getting a double bed in hotels and inns. Gays pointed out problems, since employees do not easily offer double beds to homosexuals. This fact leads the gays to go through constraints at times.

Perceived by that, that negative experiences are related to the provision of services, not to be, initially, a relevant infrastructure. Presented data from Pernambuco in 2006 , is passed to the results achieved with the interviews conducted in 2010.

\begin{tabular}{|c|c|}
\hline \multirow{3}{*}{ Service } & $\begin{array}{l}\text { In London, I was having a hard time communicating, the employee understood that I was a Portuguese speaker } \\
\text { and immediately called a central service where I could speak my own language and have it translated to him [...] } \\
\text { I thought it was perfect, the fact that he cared about it (Evandro Mota-RN) }\end{array}$ \\
\hline & The receptionist's service provision, kindness, courtesy, quick service, no one was left waiting. (Dário Varela-RN) \\
\hline & [...] personal service, being treated by one's own name. Being agile, effective, courteous. (Cláudio Abreu-PE) \\
\hline \multirow{2}{*}{ Absence of prejudice } & $\begin{array}{l}\text { I've never felt the effects of prejudice, even though everyone knows I'm overly gay. When we get around it can } \\
\text { be noticed, it's clear [...] they are there to provide a good service, be you straight, or overly gay (Zuca Maia-RN) }\end{array}$ \\
\hline & [...] that would be the service, being respected, treated well. (Cláudio Abreu-PE) \\
\hline \multirow{3}{*}{ Breakfast } & [...] an interesting breakfast. I really like everything from breakfast. (Zuca Maia-RN) \\
\hline & {$[\ldots]$ the option of having breakfast included. (Ylma Maia-PE) } \\
\hline & $\begin{array}{l}\text { Wonderful breakfasts, lots of breads, lots of fruits [...] an incredible variety, I believe breakfast is an extremely } \\
\text { important item, you see? (Laura Freitas-PE) }\end{array}$ \\
\hline \multirow{3}{*}{ Internet } & [...] wireless internet. (Zuca Maia-RN) \\
\hline & It must offer an internet zone. (América Revoir-RN) \\
\hline & Has free internet access. (Ylma Maia-PE) \\
\hline \multirow{2}{*}{ Cleanliness } & [...] it's about the hotel's organization and cleanliness, it's essential. (Ylma Maia-PE) \\
\hline & Cleanliness, I think it's extremely important.[...]. Not only bedrooms but social areas as well. (Olga Benário-RN) \\
\hline \multirow{2}{*}{$\begin{array}{l}\text { Privacy and } \\
\text { discretion }\end{array}$} & It's always good [...] being equally served. [...] privacy, we want privacy. (América Revoir-RN) \\
\hline & There's privacy within the bedroom [...]. (Luisa Lago-PE) \\
\hline
\end{tabular}

Table 5 Positive consumption experiences - Service provision (2010). Source: data collected in 2010
[...]Then my friend asked for one thing and the attendant responded with ill will, said they didn't have it, and would not do it - if she wanted that she should pay to get it [...]. (Eduardo Assis)

Service

$[\ldots]$ they gave us the key but when we got there it wasn't our room, there was someone else [...]. (Gabriel Montenegro)

[...] a bad hotel can ruin your trip. I was traumatized by the hotel in Florence; you end up associating that bad experience at the hotel to the city. [...] Once in the bedroom, the bathroom! I'm disgusted by Cleanliness a dirty bathroom [...]. (Gabriel [...] it cannot have that mold smell [...]. (Pedro Assis)

[...] the bathroom was not hygienic [...]. (Eduardo Assis)

Table 4 Negative consumption experiences - Service provision (2006). Source: data collected in 2006 


\section{Male and female gay's reports - Pernambuco and Rio Grande do Norte (2010)}

In the following tables, interviewees' names are represented by pseudonyms along with the abbreviation of the States where the interviews were conducted. It was identified that with regard to service provision, the service, absence of prejudice, breakfast, internet, cleanliness, privacy and discretion are important in order to build a positive and memorable consumer experience. The framework presents five extracts of the narratives of the interviewees where evidences that guided the construction of the categories can be observed.

Comparing results from 2006 with the data collected in 2010, it was found that service, breakfast, privacy and discretion are common categories of data collected in both periods. Besides those, the respondents of 2010 added the absence of prejudice, the Internet and cleanliness as aspects that may also lead them to positive consumer experiences. The absence of prejudice is highlighted only by gay men; on the other hand, the Internet and cleanliness are important to gays of both genders and States.
In the segment of positive experiences, infrastructure also plays a role. The bed, a differentiated structure, the pool and other social areas, bedroom and technology are the categories that influence positively the stays of gays in hotels and inns (see Table 6).

The bed, the differentiated structure and the pool were items that provided positive experiences for respondents in 2006 as well as in 2010 . However, the cable TV was only relevant to the respondents in the first period, while the bedroom and technology were emphasized by people who were part of research in 2010. The bedroom plays a prominent role for both genders in both states. Moreover, technology only provided positive memorable experiences for gays from Rio Grande do Norte.

Another important aspect of data obtained in 2010, is that the pool is related to other social areas that allow moments of social interaction. Please note that only gay men in Pernambuco recognize these areas as special.

Finally, location also plays a role in the process of consumption (see Table 7). This memory remains in the memories of the individuals interviewed in both periods. It was noted that location was emphasized, mainly by res-

\begin{tabular}{|c|c|}
\hline \multirow{2}{*}{ Bed } & $\begin{array}{l}\text { The first thing I check in the room is the bed. It must be tidy, clean, this way we already feel more at ease. }[\ldots] \text {. } \\
\text { The sheet has to be nice }[\ldots] \text { mainly because at the hotel we usually require more than at home. }[\ldots] \text { I check the } \\
\text { mattress [...]. (América Revoir-RN) }\end{array}$ \\
\hline & $\begin{array}{l}{[\ldots] \text { the nights of good sleep because the bed was wonderful [...] goose feather pillows, Egyptian linens, nice bed. }} \\
\text { The hotel in Pipa, } \mathrm{R} \$ 800,00 \text { per night. (Cláudio Abreu-PE) }\end{array}$ \\
\hline \multirow{4}{*}{$\begin{array}{l}\text { Differentiated } \\
\text { structure }\end{array}$} & $\begin{array}{l}\text { Really, really good, at the Tropical Hotel in Manaus. It was about everything, it is round, there's a water park in } \\
\text { the middle [...] the river is huge [...]. By nature, at an exotic city. [...]. Many hotels excite us because of the } \\
\text { structure. [...]. (Zuca Maia-RN) }\end{array}$ \\
\hline & $\begin{array}{l}\text { This hotel is huge, it's colonial, takes an entire block in São Paulo [...] it has a library, lots of history. [...]. The one } \\
\text { in Brasília had a huge piano [...] there was a lot of things in that ambient [...] that was new for me, things we } \\
\text { don't find in any hotel. (América Revoir-RN) }\end{array}$ \\
\hline & $\begin{array}{l}{[\ldots] \text { a little treat when you arrive. A basket of fruits }[\ldots] \text { a turndown service, a chocolate, a little liqueur. }[\ldots] \text { you }} \\
\text { notice that the establishment is working with pleasure. (Cláudio Abreu-PE) }\end{array}$ \\
\hline & $\begin{array}{l}{[\ldots] \text { a hotel I stayed in Amsterdam that took details and comfort to another level. The mattress was filled with }} \\
\text { goose feathers, so I thought it was amazing. (Evandro Mota-RN) }\end{array}$ \\
\hline \multirow{3}{*}{$\begin{array}{l}\text { Pool and other social } \\
\text { areas }\end{array}$} & $\begin{array}{l}\text { These common areas that are really pleasant, well designed and accessible [...] areas you can actually make use } \\
\text { of. [...]. I really enjoyed the gardens and the pool. I really like trees and plants. (YIma Maia-PE) }\end{array}$ \\
\hline & The pool, because I enjoy the sun, I like to be in the water, that's a personal characteristic. (Luisa Lago-PE) \\
\hline & Pool, because it's exactly the contact with nature, calmness, water, I really like swimming. (Cláudio Abreu-PE) \\
\hline \multirow{3}{*}{ Bedroom } & $\begin{array}{l}\text { You have privacy, you say what you want, you can have fun, chat, and it all becomes much more comfortable } \\
\text { when lying in bed. (Ylma Maia-PE) }\end{array}$ \\
\hline & $\begin{array}{l}\text { The bedroom is where I spend most of the time; it's where I feel at home. [...]. I really like the bedroom (Zuca } \\
\text { Maia-RN) }\end{array}$ \\
\hline & The bedroom, I feel good, free, at ease. (Olga Benário-RN) \\
\hline \multirow{3}{*}{ Technology } & $\begin{array}{l}\text { So you receive the card, get to the door and have to guess that the door will open once you insert the card. At } \\
\text { the first time I was surprised. That stuck to my mind because it was a new experience, it was different, it was } \\
\text { positive. [...] (Olga Benário-RN) }\end{array}$ \\
\hline & $\begin{array}{l}\text { I just had this experience; I had never seen such thing. A self service machine for everything, I thought it was } \\
\text { perfect, didn't have to bother anyone. [...]. Self service is perfect. (Evandro Mota-RN) }\end{array}$ \\
\hline & $\begin{array}{l}\text { I stayed at an odd hotel in SãoPaulo, the Formule } 1 . \text { I quite like it, despite its odd characteristics [...]. First the } \\
\text { double bed, the toilet apart from the shower, but I enjoyed it. [...] it's not expensive [...] good location. (América } \\
\text { Revoir-RN) }\end{array}$ \\
\hline
\end{tabular}

Table 6 Positive consumption experiences - Infra-structure (2010). Source: data collected in 2010 


\begin{tabular}{|l|}
\hline $\begin{array}{l}\text { It was close to town, easy to move around, meet people. [...]. To me getting around the city is more interesting than } \\
\text { staying inside the hotel. (Roni Rodrigues-PE) }\end{array}$ \\
\hline [...] the hotel location, easiness to get around the city [...]. (Dário Varela-RN) \\
\hline First the location [...]. Easy access to transports (Luisa Lago-PE) \\
\hline Firstly, I search for location [...]. (Olga Benário-RN) \\
\hline
\end{tabular}

Table 7 Positive consumption experiences - Location (2010). Source: data collected in 2010

\begin{tabular}{|c|c|}
\hline \multirow{2}{*}{ Service } & $\begin{array}{l}\text { [...] I asked something and the employee turned away from me, it happened and I don't like } \\
\text { it. (Evandro Mota-RN) }\end{array}$ \\
\hline & $\begin{array}{l}\text { Because once I was roaming around the hotel searching for the elevator, I kept asking how to } \\
\text { get there [...] I couldn't find it. I mean, the receptionist's willingness. (Evandro Mota-RN) }\end{array}$ \\
\hline \multirow[b]{2}{*}{ Breakfast } & $\begin{array}{l}\text { One thing I didn't like was that they charged for breakfast, which costed about } R \$ 15 .[\ldots . .] \text { that } \\
\text { means, I was paying just for the room [...] (Ylma Maia-PE) }\end{array}$ \\
\hline & $\begin{array}{l}\text { Negatively, I had awful experiences at inns that offered really bad or no breakfast at all. [...] } \\
\text { The food was either late or sitting there for too long, not tasteful, cold, or there was a lack of } \\
\text { options, no fruits. (Lara Freitas-PE) }\end{array}$ \\
\hline \multirow{3}{*}{ Cleanliness } & Why we left that hotel? Hygiene issues. [...] (América Revoir-RN) \\
\hline & $\begin{array}{l}\text { Regarding room service, for example, all negative memories I can remember have to do with } \\
\text { having to ask people to come around and get the room cleaned. (Lara Freitas-PE) }\end{array}$ \\
\hline & $\begin{array}{l}\text { A negative thing... maybe cleanliness, it bothers me, the fact that I don't know who had } \\
\text { stayed in that room before, sometimes old equipment. I'm concerned about hotel } \\
\text { cleanliness (Dário Varela-RN) }\end{array}$ \\
\hline \multirow[b]{2}{*}{ Privacy } & $\begin{array}{l}\text { [...] privacy. Because there are times when the maid wants to enter the room and we'd } \\
\text { rather stay there. Sometimes it's annoying. [...] (Zuca Maia-RN) }\end{array}$ \\
\hline & $\begin{array}{l}\text { I've been to hotels where the other guests acted as if they were home, they were really loud. } \\
\text { [...] some people just behave badly anywhere. (Luisa Lago-PE) }\end{array}$ \\
\hline \multirow{2}{*}{$\begin{array}{l}\text { Limited operating } \\
\text { hours }\end{array}$} & $\begin{array}{l}\text { Restrictions, [...] I was bothered because I couldn't use the pool after } 8 \text { p.m., this kind of } \\
\text { thing. (Laura Freitas-PE) }\end{array}$ \\
\hline & $\begin{array}{l}\text { [...] a restaurant service you can count on, I sense a lack of it. You can't have a proper meal at } \\
\text { the hotel after } 11 \text { p.m. That's why location is also important. (Dário Varela-RN) }\end{array}$ \\
\hline
\end{tabular}

Table 8 Negative consumption experiences - Service provision (2010). Source: data collected in 2010

pondents who had travelled abroad.

As to negative consumer experiences, they occurred due to service provision issues (see Table 8) but also due to infrastructure problems (see table 9). The service, breakfast, cleanliness, privacy and limited operating hours, can also influence the consumer experience negatively.

When analyzing the data acquired in the two stages of collection, it was identified that when there are failures, service and cleanliness are crucial for the consumers to retain possible problems related to these categories in their memory. The availability of double beds was pointed out only by 2006's respondents, while the homosexuals interviewed on the second period of research indicated that breakfast, privacy and limited operating hours, when related to undesirable situations, reflect on negative consumption experiences.

As for the data collected in 2010 in the State of Pernambuco, regarding breakfast, problems related to situations when food was not served abundantly, meals didn't have the desired flavor and mainly when it's not previously charged (included). This was reminded by les- bian interviewees. On the other hand, limited operating hours and privacy were memorized by both genres, from both states.

Finally, in contrast, to 2006's findings, the infrastructure influences the results of guests' stays; perhaps, this observation is a consequence of the inclusion of RN's participants on the research. The distance between tables in the restaurant was only remembered by gays from Rio Grande do Norte. Besides that, it was also verified that among those who identified problems in the physical infrastructure, the majority also resides in Rio Grande do Norte (see Table 9).

\section{Results and discussion}

The way service is provided unfolds as positive or negative to clients. This social factor is acknowledged by Baker, Parasuraman and Grewal (1994) as primordial to social relations developed in the servicescape. In this research, according to homosexual respondents, the behavior of employees in hotels and inns was relevant, corroborating what is postulated by Knutson and Beck (2003). 


\begin{tabular}{|c|l|}
\hline \multirow{4}{*}{$\begin{array}{c}\text { Distance between } \\
\text { restaurant tables }\end{array}$} & $\begin{array}{l}\text { One thing I don't like at restaurants is when everything seems too tight and crowded [...]. } \\
\text { (América Revoir-RN) }\end{array}$ \\
\cline { 2 - 2 } & $\begin{array}{l}{[\ldots] \text { usually, the restaurant tables are too tight and almost one over the other [...] the }} \\
\text { space could be harmonious accordingly to its size (Dário Varela-RN) }\end{array}$ \\
\cline { 2 - 2 } & {$[\ldots]$ that the tables were more apart, offering more privacy. (Olga Benário-RN) } \\
\hline \multirow{5}{*}{ Physical infrastructure } & $\begin{array}{l}\text { For example, the cheaper ones usually present some maintenance issues. We were on the } \\
\text { elevator and the mirror was broken. (Zuca Maia-RN) }\end{array}$ \\
\cline { 2 - 2 } & $\begin{array}{l}\text { Uncomfortable beds and pillows, malfunctioning TVs, even though I don't usually watch it } \\
\text { but then it won't work when you intend to do so. [...] Electric shocks from water faucets } \\
\text { (Lara Freitas-PE) }\end{array}$ \\
\hline
\end{tabular}

Table 9 Negative consumption experiences - Infra-structure (2010). Source: data collected in 2010

Thus, employee performance is considered the most important asset of hotels in order to a stay to be classified by guests as free of worries. (Dube, Le Bel y Sears, 2003).

Privacy and discretion offered - or not - by hotel employees can also reflect on memorization of the consumer experiences. The need to privacy and discretion is essential to gays, confirming what has been stated by Nunan (2003) regarding the search for freedom. The quest for privacy also relates to the preference of having more distance between tables in the hotel restaurant.

They also look for places that have absence of prejudice, this finding strengthens Poria's (2006) argumentation: gays want to be treated the same way as heterosexual clients. There's a search for the social comfort (Butcher, 2005) that depends on the behavior of others and employees in the service environment.

The categories breakfast, internet, technology and cable television are understood as extrinsic benefits. Knutson and Beck (2003) presented the consumer experience (in hospitality) construction model and through this demonstrated that this kind of benefit affects the essential step of the consumption process that is the participation.

It was also noticed that the issue of cleanliness in hotels in general is essential for homosexuals to remain, return or choose an establishment of this kind. This statement goes against what was found in the study by Baker, Parasuraman and Grewal (1994), which considers that aesthetic and design factors of the environment, among them cleanliness do not affect the inferences about the service quality. However, Turley and Milliman (2000) do recognize its importance.

As for the bed in hotel apartments, it should be "large" (Pedro Araujo), "soft" (João da Silva) and "comfortable" (Pedro Araujo, Eduardo Assis, João da Silva) in order to create a positive consumer experience. This statement is in accordance with Dube, Le Bel and Sears (2003), they indicate that the style of apartment is a component of the stay that may lead to comfort provision. In that sense, the findings of this research present the room as important. Another fact is that, according to the study by Poria (2006), there was evidence that the homosexual demand double beds.

Besides that, homosexual interviewees value diffe- rentiated structures, because that makes it possible for them to have different experiences in hotels or inns. This result agrees with the work presented by Nunan (2003), by emphasizing that homosexuals value fashion and appreciate what is different, thus, it is necessary the hotel should consider the physical structure of the establishment in order to impress these guests.

Regarding the pool and social areas, when consumers want to interact with other individuals the presence of others in the environment results in positive behavior because they enjoy their free time on site (Backer y Cameron, 1996). Furthermore, the model of Knutson and Beck (2003) contributes to this acknowledgement by previously stating that the interaction with other individuals also influences the guest's experience.

Regarding the location, the testimonials of respondents agree with the works of Turley and Fugate (1993). The authors state that location is an important element when it comes to accessibility and proximity. Thus, the location where the service is offered influences the value of experience for consumers (KNUTSON; BECK, 2003).

Finally, limited operating hours or rules were not addressed Knutson and Beck's (2003) model. Only Poria (2006) identified that gay men prefer extended breakfast periods. Given the data, it could be observed that some of the interviewees feel uncomfortable with the existence of such rules in the hospitality service.

\section{Final considerations}

The overall goal of identifying the consumer experiences at hotels and inns that are memorable for homosexual respondents was achieved, and these experiences identified as positives and negatives. The service, absence of prejudice, breakfast, internet, cleanliness, privacy and discretion (service provision) as well as, the bed, differentiated structure, the pool and other social areas, the bedroom, technology and cable TV (infrastructure) and location are recognized as factors that could cause a consumer experience to be remembered positively. The negatives result of failures in service, breakfast, cleanliness, lack of privacy, availability of double beds and limited operating hours (service) and problems regarding the physical 
structure and the short distance between restaurant tables (infrastructure).

It was observed that few differences were found between genders with regard to elements that foster memorable consumer experiences. Otherwise, additional factors have emerged in 2010; perhaps it could be explained by the inclusion of lesbians, as well as individuals from Rio Grande do Norte in the research scope.

Therefore, the service environment of hotels and inns influences the consumer experiences of the interviewed homosexuals. Thus recognizes that consumption is influenced by environmental factors of the servicescape, including the social aspect, along with the role of hedonic perspective in the process of consumption (Hirschman y Holbrook, 1986; Woods, 1960). However, considering the relevance of the theme and the shortcomings of this investigation, it is indicated further research on this subject in future studies.

\section{Literature cited}

Albandes-Moreira, L. A.

2002 "An Exploratory Study on the Nature of the Representations of Organization, manager and management within a group of teachers of a business school". Tese (Doutorado) - École des Hautes Études Commerciales, Montreal, Quebec.

Baddeley, A.

1994 "The magical number seven: still magic after all these years?" Psychological Review, 101(2): 353-356.

Bacha, M. de L.; Strehlau, V. I. y Romano, R.

2006 "Percepção: termo freqüente, usos inconseqüentes em pesquisas?" En: Anais... EnAnpad, Salvador.

Bayton, J. A.

1958 "Motivation, Cognition, Learning: Basic Factors in Consumer Behavior" The Journal of Marketing, 22(3): 282-289, Jan.

Berry, Leonard L.; Carbone, Lewis P. y Haeckel, Stephan $\mathrm{H}$.

2002 "Managing the total customer experience" $M I T$ Sloan Management Review, 43(3): 85-89.

Bitner, Mary Jo, Faranda, William T., Hubbert, Amy R. y Zeithaml, Valarie A.

1997 "Customer contributions and roles in service delivery” International Journal of Service Industry Management, 8(3): 193.

Bogdan, Roberto C. y Biklen, Sari K.

1994 Investigação qualitativa em educação. Porto: Porto Editora.

Butcher, Ken.

2005 "Differential impact of social influence in hospitality encounter" International Journal of Contemporary Hospitality Management, 17(2): 125-135.

Delozier, Wayne M. y Rodrigue, Jason.

1996 "Marketing to homosexual (gay) market: a profile and strategy implications" En: Wardlow, D. L. (Org.). Gays, lesbians and consumer behavior: theory, practice and research issues in marketing. (pp. 203-211). New
York: Harrington Park Press.

Dube, Laurette; Le Bel, Jordan y Sears, Donna.

2003 "From Customer Value to Engineering Pleasurable Experiences in Real Life and Online" Cornell Hotel and Restaurant Administration Quarterly, 44(5/6): 124-131.

Fugate, Douglas L.

1993 "Evaluating the Us Male Homosexual and Lesbian Population as a Viable Target Market Segment" Journal of Consumer Marketing, 10(4): 46-57, 1993.

Gutiérrez, Melissa Rodriguez.

s/d Mercadotecnia emocional. Disponível em: <http:// www.gestiopolis.com/recursos2/documentos/fulldocs/ mar/mktemocio.htm>. Acesso em: 20/jul/2006.

Haslop, Craig; Hill, Helene y Schimidt, Ruth A.

1998 "The gay Lifestyle- Spaces for a Subculture of Consumption" Marketing Intelligence \& Planning, 16(5): 318-326.

Hirschman, Elizabeth C. y Holbrook, Morris B.

1986 "Hedonic consumption: emerging concepts, methods and propositions" Journal of Marketing, 46: 92-101.

Holbrook, Morris B. y Hirschman, Elizabeth C.

1982 "The experiential aspects of consumption: consumer fantasies, feelings, and fun" Journal of Consumer Research, 9(2): 132-140, Sep.

Hooley, G. J.; Saunders, J. A. y Piercy, N. F.

2005 Estratégia de marketing e posicionamento competitivo. São Paulo: Pearson.

Hughes, Howard L.

2002 "Marketing gay tourism in Manchester: new market for urban tourism or destruction of "gay space"?" Journal of Vacation Marketing, 9(2): 152-163.

Jacoby, J.

1977 "Information load and decision quality: some contested issues" Journal of Marketing Research, 14(4): 569-573, Nov.

Jacoby, J.

1978 "Consumer Research: A state of the art review". The Journal of Marketing, 42(2): 87-96, Apr.

Jones, David A.

1996 "Discrimination against same-sex couples in Hotel" En: Wardlow, D. L. (Org.). Gays, lesbians and consumer behavior: theory, practice and research issues in marketing. (pp. 153-159). New York: Harrington Park Press.

Kates, Steven M.

1998 Twenty million new customers! Understanding gay men's consumer behavior. New York: Harrington Park Press.

Knutson, Bonnie J. y Beck, Jeffrey A.

2003 "Identifying the dimentions of the experience construct: development of the model" Journal of Quality Assurance in Hospitality \& Tourism, 4(3/4): 23-35.

Lally, A. M. y Fynes, B.

2006 "Articulating service concept to enhance tourism experience design". Annual Conference of the Irish Academy of Management: 1-25.

Lukenbill, Grant. 
1999 Untold millions: secret truths about marketing to gay and lesbian consumers. New York: Harrington Park Press.

Malhotra, N. K.

1982 "Information load and consumer decision making" The Journal of Consumer Research: 8(4): 419-430, Mar.

McDaniel, Carl y Gates, Roger.

2005 Pesquisa de marketing. São Paulo: Thomson.

Merriam, Sharan B.

1998 Qualitative research and case study applications in education. San Francisco: Jossey-Bass.

Miller, G.

1956 "The Magical Number Seven, Plus or Minus Two: Some Limits on Our Capacity for Processing Information” The Psychological Review, 63(2): 81-97, Mar.

Mowen, J.C. y Minor, M. S.

2003 Comportamento do consumidor. São Paulo: Pearson.

Newman, P. J. y Nelson, M. R.

1996 "Mainstream legitimization of homosexual men through valentine's day gift-giving and consumption ritual" En: Wardlow, D. L. (Org.). Gays, lesbians and consumer behavior: theory, practice and research issues in marketing (pp. 57-69). New York: Harrington Park Press.

Nunan, Adriana y Jablonski, Bernardo.

2002 "Homossexualidade e preconceito: aspectos da subcultura homossexual no Rio de Janeiro" Arquivos Brasileiros de Psicologia, 54(1): 21-32.

Nunan, Adriana.

2003 Homossexualidade: do preconceito aos padrões de consumo. Rio de Janeiro: Caravansarai.

Oakenfull, G. K. y Greenlee, T. B.

2005 "Queer eye for a gay guy: using market-specific symbols in advertising to attract gay consumers without alienating the mainstream" Psychology \& Marketing, 22(5): 421-439, May.

Oliveira, Luciano Amaral.

2002 Turismo para gays e lésbicas: uma viagem reflexiva. São Paulo: Rocca, 2002.

Oliveros, M. E. G. y López, V. G. A.

2006 "Compra impulsiva en el homosexual masculino Estudio exploratorio en la ciudad de Barranquilla (Colombia)" Pensamiento y Géstion, 20: 125-164.

Patton, Michael Quinn.

2001 Qualitative research and evaluation methods. California: Sage Publication.

Penãzola, L.

1996 "We're here, we're queer, and we're going shopping! A critical perspective on the accommodation of gays and lesbians in the U.S. marketplace" En: Wardlow, D. L. (Org.). Gays, lesbians and consumer behavior: theory, practice and research issues in marketing. (pp. 9-41). New York: Harrington Park Press.

Pereira, Bill Nunes; Ayrosa, Eduardo André Texeira y Ojima, Sayuri.

2005 "Consumo entre gays: compreendendo a construção da identidade homossexual através do consumo". En:
Encontro Anual Da Anpad, 29. Anais... Brasília: ANPAD.

Pine, J. y Gilmore, J. H.

1998 "Welcome to the experience economy" Harvard Business Review, 76(4): 97-105.

Poria, Yaniv.

2006 “Assessing Gay Men and Lesbian Women's Hotel Experiences: An Exploratory Study of Sexual Orientation in the Travel Industry" Journal of Travel Research, 44(3): 327-334.

Pullman, Madeleine E. y Gross, Michael A.

2003 "Welcome to your experience: where you can check out anytime you'd like, but you can never leave" Journal of Business and Management, 9(3).

Reiss, M. C. y Webster, C.

1997 "Relative influence in purchase decision making: married, cohabitating, and homosexual couples" Advances in Consumer Research, 24: 42-47.

Ruangwanit, N. y Wattanasuwan, K.

2009 "Living in double world: harmonizing homosexuality and masculinity through symbolic consumption in private space" Advances in Consumer Research, VIII: 137-143.

Saura, Irene G.; Pérez, Manuel S.; Contrí, Gloria B. y González-Gallarda, Martina.

2005 "Encuentro de servicio, valor percibido y satisfacción del cliente en la relación entre empresas" Cuadernos de Estudios Empresaeiales, (15): 47-72.

Schmitt, Bernd H.

1999 "Experiential marketing" Journal of Marketing Management, 15: 53-67.

Schmitt, Bernd H.

2002 Marketing experimental. São Paulo: Nobel.

Shimp, T. A.

2003 Propaganda e promoção: aspectos complementares da comunicação integrada de marketing. 5. ed. São Paulo: Bookman.

Solomon, M. R.

2008 O comportamento do consumidor. 7. ed. Porto Alegre: Bookman.

Visconti, L. M.

2008 "Gays' market and social behaviors in (de)constructing symbolic boundaries". Consumption Markets \& Culture, 11(2): 113-135, June.

Taylor, Steven J. y Bogdan, Robert.

1984 Introduction to qualitative research methods: the search for meanings. (pp. 123- 145). John Wiley \& Sons. 2. ed.

Turley, L. W. y Fugate, Douglas L.

1992 "The multidimensional Nature of service facilities:viewpoints and recommendations" The Journal of Services Marketing, 6(3): 37-46.

Turley, L.W. y Milliman, R. E.

2000 "Atmospheric Effects on Shopping Behavior: A review of the Experimental Evidence" Journal of Business Research, 49: 193-211.

Waitt, Gordon y Markwell, Kevin.

2006 Gay tourism: culture and context. New York: 
Haworth Hospitality Press.

Wikström, Solveig.

s/d When products and service are not enough. Disponível em: <http://www.ecr-academics.org/journal/archive/ pdf/when\%20products\%20and\%20services.pdf $>$. Acesso em 19/jul/2006.

Woods, W. A.

1960 "Psychological dimensions of consumer decision" The Journal of Marketing, 24(3): 15-19.

Zaichkowsky, J. L.

1985 "Measuring the involvement construct" The Journal of Consumer Research, 12(3): 341-352.

Recibido:

$14 / 01 / 2011$

Reenviado:

$01 / 09 / 2011$

Aceptado:

$09 / 09 / 2011$

Sometido a evaluación por pares anónimos 